\title{
Labour Commitment and Firm's Productivity in Nigeria: A Case Study of Global Soap and Detergent Industries Limited, Ilorin, Kwara State.
}

\author{
Adelowo Wahab Bashir \\ Economic Policy Research Department, \\ Nigerian Institute of Social and Economic Research (NISER), \\ PMB 5, U.I Post Office, Oyo Road, Ojoo, Ibadan, Nigeria.
}

\begin{abstract}
This study attempts to find the relationship that exists between labour commitment and firm's productivity. It also examines the impact of employees' sex, marital status and occupational status on commitment to work. One hundred workers were drawn as sample from Global Soap and Detergent Industries Limited, Ilorin, to aid the research. An instrument title "Labour commitment and productivity Questionnaire" $(L C P Q)$ was used for collecting data which was analyzed with statistical tables, simple percentage and chisquare statistics. The findings showed a high positive relationship between labour commitment and productivity. Also, the study revealed a significant difference in the commitment to work of married and single employees, male and female employees as junior and senior company employees. Therefore, the management should shelve away the idea of leadership styles who believes that productivity and profit are the goals of an enterprise without considering the plight of the workers. Rather they should try as much as possible to make sure that workers are credited for a job well done. Apart from giving workers more pay, their promotion must also be regular. Lastly, the agreement ever reached with the union should be met.
\end{abstract}

Keywords: Labour, Commitment, Firm's, Productivity, Employers' and Employees'

\section{Introduction}

Labour is an important and infact, indispensable factor of production. A business firm employs workers to do several types of job. The use of labour is quite prevalent in the business operations whether it is production of goods and services or trading. A hundred percentage automation of any firm is rather impossible. At least, men would be required to press the bottons if the firm uses computers to control operations of its business. Labour is thus an unavoidable input in production process. Considering the important of labour input, it will be quite natural for a firm to lay emphasis on its efficient utilization. The firm spends moneys on employment of labour, it will ensure that the gain from such employment is maximized. It is worth nothing that in the 1960s through 1970s, workers were more committed and the productivity level was highly improved. This situation arose from the fact that the little salaries paid to the worker by then, attracted very high value and the purchasing power of the money too, was high. While from early 1980s, there has been a downward trend in productivity and sloppy economic performance.

Commitment is therefore a major potential source of such gain. The employer must be sure that such employee who hates his/her job may not leave because there is nothing else that pays as well. He/she may become less committed to the job, and as such, labour productivity will be low. Dissatisfaction with work is the greatest factor that contributes to low labour productivity. When allowed to operate freely, job satisfaction can contribute substantially to labour effectiveness as well as productivity. A worker that is committed to his/her job will be punctual to work, avoid absenteeism, and show the willingness to exert considerable effort on behalf of its organization. Miner $(1985,1988)$ opined that there is strong relationship between workers' commitment and productivity. He stressed that high commitment is positively related to low absenteeism and high productivity.

With the advent of structural adjustment programme in 1986, the capacity utilization of the industrial organization had shrunk to an all time low level and this constitutes serious threat to the national economy. In some quarters, the reason has been attributed to declining motivation to worker, poor work attitude and bad work ethics. In some other quarters, the reason lies in government or employers insensitivity to workers concern and resultant deteriorating standard of living, incessant strike actions by labour/ trade unions. To reverse this ugly trend, organizations must address the people's concern. Employers must restructure their human resource programmes with a view to placing higher premium on the development of workers' capability and the improvement of their quality of works life (Bassey; 1995). This study therefore established the relationship between labour commitment and firm's productivity, find the difference in the impact of female commitment and male commitment to work on productivity, examine the difference in the commitment to work of married 
and single employee and finally find the difference in the exhibition of commitment by junior and senior workers.

\subsection{Conceptual Framework}

\section{Literature Review}

Most researchers of commitment treat the business firm as a unitarist organization, with one set of goals, values and beliefs to which all organizational members subscribe. It follows that the committed employee is someone who is committed to the whole organization, including upper management front-line supervisors and coworkers. Conversely, an uncommitted employee is someone who is not committed to anyone in the organization. Therefore, employee commitment is logically inseparable from organization commitment. Scholars have defined the concept of labour commitment in various ways. For instance, Buchanan (1974) draws together three elements of commitment: identification with the goals and values of the organization, involvement in work role and a sense of loyalty to the organization. According to Hall et al. (1970) "The process by which the goals of the organization and those of the individual become increasingly integrated or congruent" is commitment. Salancik (1977) said commitment is that "a state of being in which an individual become bound by his action and through these action to beliefs that sustain the activities of his own involvement". Mowday et.al in (1979) defined commitment in such a way "... The relative strength of an individual's identification with and involvement in a particular organization". Scholl (1981) described "...a stabilizing force that acts to maintain behavioural direction when expectancy/equity conditions are not met and do not function." Allen \& Mayer (1991) claim that commitment is “... a psychological state that bind the individual to the organization". According to the Meyer \& Allen (1997) commitment "is a psychological state that characterizes the employees' relationship with the organization and has implication for the decision to continue membership in the organization."

From the above definitions, one can deduce the basic characteristics of labour commitment as follows: employees' strong desire to stay and to accept the organization's major goals and values; His willingness to exert high level of effort on behalf of the organization and to have a high degree of loyalty and belongingness to the organization.

\subsection{Theoretical Framework}

It is generally believed that both capital and labour are the major factor inputs. Notwithstanding, to ensure increase in productivity, other factors like commitment must be considered. Commitment is therefore a psychological term. In economic term, commitment simply means efficiency of labour.

Ghosal and Ghosh (1964) stated that an increase in production is not necessarily accompanied by an increase in productivity; indeed, sometimes the reverse is the case. A conclusion about productivity cannot, therefore, be reached without considering the changes in inputs that are require to improve output. Production is the creation of wealth which in turn adds to society's welfare. It is a vital link in the process of satisfying human wants, and thus requires that scarce resources be used efficiently in order to create the maximum possible welfare. Labour commitment is a way of utilizing the factors (labour) efficiently. Utilizing factors of production efficiently to produce more output is referred to as "Total Factor productivity" (TFP). Total Factor Productivity explains the residual output that cannot be accounted for by traditional factor inputs of labour and capital. The unexplained portion has been attributable to as efficiency (Lowery et al; 2002) or commitment in terms of labour.

Solow (1957) and Denison (1962) in their studies concluded that it is the human factor, in the form of better organization, professional skills and technical knowledge, which accounts for the residual output. Denison (1962) also shows that residual productivity (caused by labour commitment and efficiency use of capital) is the biggest source of the difference in level of income per person employed between North America and Europe and between North America and the U.K. Morgan and king (1975;376), Rosenberg (1960;319), and Katz (1960;163), cited in Ajila (2000) view commitment as the study of dynamics of human behavior and that commitments have the components which are cognitive, emotional and action. Commitment to work is a complex cognitive process, but can be characteristic in tree ways;

i. $\quad$ It tends to persist unless something is to done to change it.

ii. It falls anywhere along a continuum from very favorable to very unfavorable.

iii. It is directed towards some aspect of the job about which a worker has feelings and beliefs. (Rosenberg, 1960).

A work related example of the three components of commitments is presented below: 


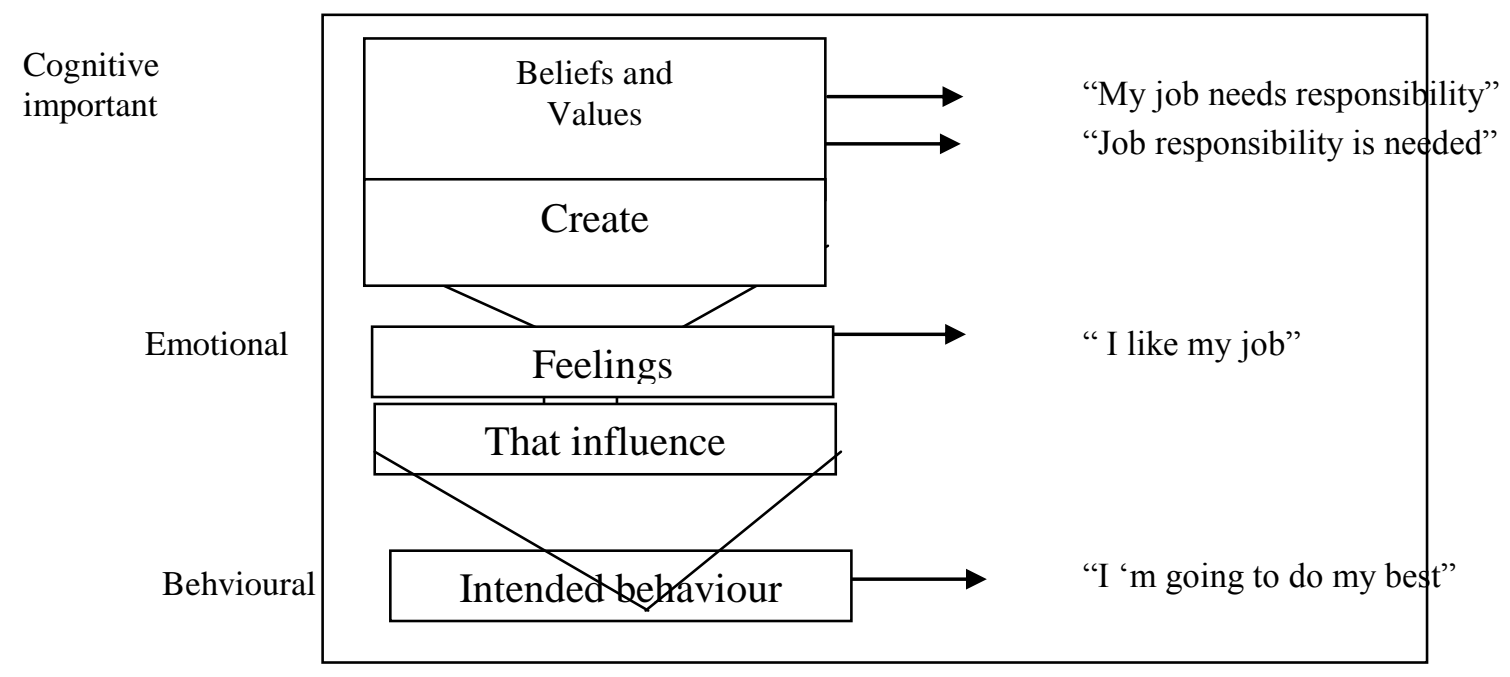

Source: Adapted from Schermerhorn, et al. (1985).

The cognitive component thereby consists of beliefs, values, and information the worker has about the job (e.g "my job needs responsibility"). The emotional component includes the worker's feelings about the job. That the worker could have a positive, neutral or negative feeling (e.g "I like my job"). Therefore, the worker's emotion about the job, influences his or her intended behavior, and the third component is behavioural which consists of a worker's tendency to behave in a particular way when given a job or in the work environment. Generally, workers with commitments to work are likely to lead to improved productivity in an organization. When commitments to work decline, they may result in wild cat strikes, work slowdowns, absence and labour turnover. They may also be a part of grievance, low performance, poor product quality, workers theft and disciplinary problems. The organization costs associated with poor worker's commitment may be astronomical. Favourable commitments to work are the products of effective behavioural management, the continuing process of building a supportive human climate in an organization. Commitment to work is very important because it helps to predict work behavior. It is thus obvious that a worker's commitment to work will determine whether he or she is satisfied with his job or not and this ultimately will affect (either positively or negatively) his productivity. Therefore successful performance of a given job is a function of ability (skill, knowledge, technology), effort (needs, rewards, expectations), and opportunity (current situation, commitment and past performance).

\subsection{Empirical Studies}

Series of research works had been carried out in this sector. This includes the work of: Francois and Roberts (2002) who were of the opinion that firm profits are determined not only by hiring and firing costs but also by the cost of effort i.e commitment of workers. This is because firms with high commitment capacity are able to extract additional effort from workers at a lower cost. And this increase in commitment power of workers allows firms to extract more rents from the employment relationship, by extracting more efforts at a lower cost. These additional rent serve to motivate innovation, and hence growth in productivity. However for an organization to achieve high level of productivity, the impact of labour commitment on firm's productivity cannot be overemphasized. A firm cannot only make profits by hiring and firing of workers but also through the commitment of its workers. They made use of Cobb-Douglas production function to maximize the utility of the firm and they came out with a conclusion that firms who are able to credibly commit to longer terms of employment can extract effort more cheaply. This therefore can increase the incentive for investment in innovation. In an environment with incomplete contracting, this suggests that the introduction of labour market frictions may be able to enhance commitment capacity and as well yields another motivation for government intervention in the labour market. Also, if capital is complementary to effort, then this should also lead to greater capital accumulation when labour market relationships are governed by internal labour markets. Varsha and Monika (2012) employed survey method with the aid of organizational commitment questionnaire (OCQ) to identify the impact of employees' commitment on sustained productivity in Auto-component Industry in India (Denso). The result revealed that there existed a positive relationship between the three commitments- affective, continuance and normative commitment and sustained productivity of the organization. Aries and Rizqi (2013) adopted survey method with the aid of Structural Equation Modelling (SEM) to explain and empirically test the effect of attitude towards work, job satisfaction, and organizational commitment to the employee's job 
performance at PT. X. The result showed that organizational commitment has a more significant effect to job satisfaction and employee's job performance at PT. X than attitude towards work. Sarah et al. (2011) used Workplace and Employee Relation Survey (WERS) with the aid of Generalized Ordered Probit to explore the relationship between employee commitments, loyalty, firm performance and labour productivity at the firm level. The result indicated that employee commitment and loyalty are positively associated with higher levels of workplace performance and labour productivity. Pritchard et al. (2002) viewed productivity as fundamentally about how productive people are at work, clearly their skills, motivation and commitment. In addition, there is a whole host of reasons for the low productivity level, but with specific regard to the workplace, the problem seems to be one of uneven application of effective management techniques and training and development opportunities. Government has introduced a number of new arrangements, including tax incentives in order to encourage employee commitment and motivation through the use of employee shareholding, with the aim of improving productivity performance.

Mitchell (1982) cited in Salawu and Adetayo (2000), explained that motivation is the actual incentive provided by an organization to its personnel to aid or enhances productivity. The fact still remains the same that all personnel are expected to have some level of incentives to commit them in order to enhance their efficiency and effectiveness which will invariably lead to high productivity. In addition, a motivated person is always ready to act and assist the organization to be more productive and mostly motivation is concerned with why people do things or refrain from doing them. Akindele (1994) 0pined that employees should be motivated by the provision of social amenities such as work recess, free access to management, adequate health care programmes for self and family, equitable work, schedule and vacations. Hence, this study focuses on the role of motivation in enhancing productivity in the Nigerian Banking Industry. Mishra and Morrissey (1990) were of the opinion that poor manager-workers relationship brings about moral depreciation. Manager should create a motivational working environment that will result in productivity. Employees prefer working with a sensitive and democratic leader to aggressive and autocratic leader.

Also, there are pertinent, recent empirical studies on the subject of Nigeria's industrial productivity. For instance; Udabah (2000) was of the view that high productivity in the industrial, agricultural and the services sectors is critical for rapid economic growth and development for a developing country like Nigeria. He also stated that such rapid growth would only be possible through an industrialization programme. In his own contribution, Anyanwu (2000) stated that there was a dearth of data on productivity levels in the Nigeria economy in general, and the manufacturing sector in particular. He, however, noted that the general downward trend in the sector's output growth, its capacity utilization rate, and its share of the Gross Domestic Product (GDP) between 1981 and 1988, were all indicative of falling productivity. According to him, studies by Enisan and Akinlo (1996) have shown that only a few industries in Nigeria had experienced rising productivity during the period of 1981 and 1988.

Most of the works on this sector in Nigeria are mainly on the attitude and motivation of labour as they affect productivity. These works include those of Ajila (1997), Ajila (2000) and Salawu and Adetayo (2000). Their work is significantly different from this study, being that the main focus of this study is on the commitment of workers as it affects productivity in the various industries in Nigeria.

\section{Methodology}

The methods adopted by this researcher in collecting the data are direct interviews, the use of questionnaire and observations. Inquiries were also made both directly and indirectly through some unusual questions to diverse groups within the firm.

\subsection{Population, Sample and Sampling Technique}

The population for this study covers all workers of Global Soap and Detergent Industries, Ilorin. In order to carry out an in-depth and comprehensive study, 100 respondents were randomly selected which was based on the stratified random sampling, such that workers are randomly selected from each of the 12 departments according to their respective population.

\subsection{Instrument}

The primary data was employed in gathering information from both the workers and the management. Interviews were also conducted with both the employers and the employees. The questionnaire consists of three sections. Sections A elicits Biometric information (Demographical data), while sections B and C contained structured items relating to the research questions that necessitated this research. The question comprises close ended and open ended questions. 


\subsection{Method of Analysis}

The data collected were analyzed using statistical tables, simple percentage and chi-square $\left(\mathrm{x}^{2}\right)$ was used in analyzing the research hypothesis.

The chi-square $\left(\mathrm{x}^{2}\right)$ is a test used to determine if observed frequencies differ significantly from frequencies expected from an assumed model, since primary data is used in this research method where frequencies of responses will be used to analyse the questionnaires administered. Then, the above statistical technique becomes the suitable method of analysis. The chi-square is represented by the formula:

$X^{2}=\sum(\mathrm{Fo}-\mathrm{Fe})$

$\mathrm{Fe}$

Where $\mathrm{X}^{2}=$ Chi-square

$\sum=$ the sum of

Fo $=$ Observed frequency

$\mathrm{Fe}=$ Expected frequency

$\mathrm{X}^{2}{ }_{\mathrm{c}}=$ Chi-square calculated

$\mathrm{X}_{\alpha}^{2}=$ Chi-square tabulated

The expected value is computed as:

$\mathrm{Fe}=\underline{\mathrm{RT} \times \mathrm{CT}}$

$\mathrm{N}$

Where $\mathrm{Fe}=$ Expected Frequency

$\mathrm{RT}=$ Row Total

$\mathrm{CT}=$ Column Total

$\mathrm{N}=$ Total Number of Observations.

Also, the chi-square tabulated (tabulated value), $\mathrm{X}_{\alpha}^{2}$ is determined by the degree of freedom (df) given as:

$\mathrm{df}=(\mathrm{r}-1)(\mathrm{c}-1)$

Where $\mathrm{df}=$ Degree of Freedom

$\mathrm{r}=$ Number of Rows

$\mathrm{c}=$ Number of Columns

Using $95 \%$ i.e 95 percent confidence level or 5 percent level of significance (as specified for social sciences) to test the hypotheses.

Decision Rule: This helps us to determine whether to accept or reject the null hypothesis on the following basis; If the calculated value of $\mathrm{X}_{\mathrm{c}}^{2}$ is greater than the tabulated value $\mathrm{X}_{\alpha}^{2}$ i.e if $\mathrm{X}_{\mathrm{c}}^{2}>\mathrm{X}_{\alpha}^{2}$, we reject the null hypothesis and conclude that the test is significant. On the other hand, if the calculated value of $\mathrm{X}^{2}{ }_{\mathrm{c}}$ is less than the tabulated value $\mathrm{X}_{\alpha}^{2}$, i.e $\mathrm{X}_{c}^{2}<\mathrm{X}^{2}{ }_{\alpha}$, then we accept the null hypothesis and conclude that the test is statistically insignificant.

\subsection{Test of Hypotheses}

\section{Results}

This section aims at testing the hypotheses formulated. The significance of this test is to possibly validate the hypotheses that are found to be true and therefore accept them. On the other hand, those hypotheses that are untrue shall be rejected and hence unacceptable.

\section{Hypothesis I}

Ho: $\quad$ There is no significant impact of labour commitment on productivity.

Table 1: Cross Tabulation of the Impact of Labour Commitment on Productivity.

\begin{tabular}{|l|l|l|l|l|l|}
\hline Variables & $\mathrm{N}$ & $\begin{array}{l}\text { Calculated } \\
\mathrm{X}_{\mathrm{c}^{-}} \text {value }\end{array}$ & $\mathrm{DF}$ & $\begin{array}{l}\text { Tabulated } \\
\mathrm{X}_{\alpha^{-}} \text {value }\end{array}$ & $\mathrm{p}$-value \\
\hline $\begin{array}{l}\text { Labour commitment } \\
\text { productivity }\end{array}$ & 100 & 696.105 & 252 & 43.773 & $<0.05$ \\
\hline
\end{tabular}

Source: Author's computation 2013.

From the table above, the findings indicate that the calculated chi-square $\left(\mathrm{X}_{\mathrm{c}}^{2}\right)$ is 696.105 , the tabulate value at 0.05 level of significance and 252 degree of freedom is 43.773 . As a result that the $\mathrm{X}_{\mathrm{c}}{ }_{\mathrm{c}}(696.105)$ is greater than the tabulated $\mathrm{X}_{\alpha}^{2}(43.773)$, the result is thus significant. Hence, the null hypothesis that there is no significant impact of labour commitment on productivity is rejected. This implies that there is significant impact of labour commitment on productivity.

Hypothesis II

Ho There is no significant difference in the impact of male and female workers commitment on productivity. 
Labour Commitment and Firm's Productivity in Nigeria: A Case Study of Global Soap...

Table 2: Cross Tabulation of Difference in the Impact of Female and Male Workers Commitment on Productivity.

\begin{tabular}{|l|l|l|l|l|l|}
\hline Variables & $\mathrm{N}$ & $\begin{array}{l}\text { Calculated } \\
\mathrm{X}_{\mathrm{c}^{-}}^{2} \text { value }\end{array}$ & $\mathrm{DF}$ & $\begin{array}{l}\text { Tabulated } \\
\mathrm{X}_{\alpha^{-}}^{2} \text { value }\end{array}$ & $\mathrm{p}$-value \\
\hline Male workers & 81 & 100.000 & 51 & 43.773 & $<0.05$ \\
\hline Female workers & 19 & & & \\
\hline
\end{tabular}

Source: Author's computation 2013.

As indicated in the table above the calculated chi-square $\left(\mathrm{X}_{\mathrm{c}}^{2}\right)$ is 100.00 , the tabulated value at 0.05 significant level and 51 degree of freedom is 43.773. Since the $X_{c}^{2}(100.000)$ is greater than the tabulated $X^{2}{ }_{\alpha}(43.773)$. The test is statistically significant. The null hypothesis that there is no significant difference in the impact of male and female workers commitment on productivity is rejected. Therefore, there is significant difference in the impact of male and female workers commitment on productivity of the firm.

\section{Hypothesis III}

Ho: There is no significant difference in the impact of married and single employees' commitment to the productivity of the firm.

Table 3: Cross Tabulation of Difference in the Impact of Married and Single Employees' Commitment to the Firm's Productivity.

\begin{tabular}{|l|l|l|l|l|l|}
\hline Variables & $\mathrm{N}$ & $\begin{array}{l}\text { Calculated } \\
\mathrm{X}_{\mathrm{c}^{-}} \text {value }\end{array}$ & $\mathrm{DF}$ & $\begin{array}{l}\text { Tabulated } \\
\mathrm{X}^{2}{ }_{\text {oc }} \text { value }\end{array}$ & $\mathrm{p}$-value \\
\hline Married employees & 46 & 77.045 & 28 & 41.337 & $<0.05$ \\
\hline Single employees & 42 & & & & \\
\hline
\end{tabular}

Source: Author's computation 2013.

The table above shows that the calculated chi-square $\left(\mathrm{X}^{2} \mathrm{c}\right)$ is 77.045 , the tabulated value at 0.05 level of significance and 28 degree of freedom is 41.337. Since the $X^{2} c(77.045)$ is greater than the tabulated $X^{2} \alpha$ (41.337), the result is thus significant. The null hypothesis that there is no significant difference in the impact of married and single employees' commitment to the productivity of the firm is rejected. Thus, there is significant difference in the impact of married and single employees' commitment to the productivity of the firm.

Hypothesis IV

Ho: There is no significant difference in the impact of junior and senior employees to the productivity of the firm.

Table 4: Cross Tabulation of Difference in the Impact of Junior and Senior Employees' Commitment to the Productivity of the Firm.

\begin{tabular}{|l|l|l|l|l|l|}
\hline Variables & $\mathrm{N}$ & $\begin{array}{l}\text { Calculated } \\
\mathrm{X}_{\mathrm{c}^{-}} \text {value }\end{array}$ & $\mathrm{DF}$ & Tabulated $\mathrm{X}_{\mathrm{oc}^{-}}^{2}$ value & $\mathrm{p}$-value \\
\hline Junior employees & 66 & 42.612 & 14 & 23.685 & $<0.05$ \\
\hline Senior employees & 34 & & & & \\
\hline
\end{tabular}

Source: Author's computation 2013.

As revealed in the table above, the calculated chi-square $\left(\mathrm{X}_{\mathrm{c}}^{2}\right)$ is 42.612 , the tabulated value at 0.05 level of significance and 14 degree of freedom is 23.685. Since the calculated value of 42.612 is greater than the tabulated value of 23.685 , the result is thus statistically significant. Therefore, the null hypothesis that there is no significant difference in the impact of junior and senior employees' commitment to the productivity of the firm is rejected. This implies that there is significant difference in the impact of junior and senior employees' commitment to the productivity of the firm.

\subsection{Discussion of Findings}

Discussion on this study is based on the results arrived at from the analysis of data and hypotheses testing. From the results obtained, the first hypothesis was rejected $\left(\mathrm{X}_{\mathrm{c}}^{2}=696.105, \mathrm{X}_{\alpha}{ }_{\alpha}=43.773\right)$. This suggests a significant positive impact or relationship between labour commitment and productivity. This finding agrees with the findings of Parasuraman and Alutto (1984), Reichers (1985) cited in Miner (1985). In their findings, they emphasize that high commitment is positively related to low absenteeism and high productivity. They concluded that organizational commitment lessens the chances of labour turnover while at the same time providing a reservoir of potential energy on which organization can draw in times of crises and need. At such times, commitment should yield both better attendance and improved output (productivity).

The reason for the positive impact or relationship may be connected with the fact that employees' needs are reasonably well met and the workers often make themselves available in their working place as well as avoid the attitude of going on strike and work-to-rule. Another reason for the positive impact or relationship may be as a result of workers' feeling by considering themselves as belonging to the organization. Therefore, they are interested in productivity and as well what they can benefit from the system. 
The second hypothesis was rejected $\left(\mathrm{X}_{\mathrm{c}}{ }=100.000, \mathrm{X}^{2}{ }_{\alpha}=43.773\right)$. The reason behind this fact is that though both male and female workers are subjected to some constraints. Male workers are subjected to only one constraint while the female workers are subjected to two different constraints. For the female workers, the two constraints subjected to, are organizational authority constraint and family responsibilities constraints. Due to this, they have to pay more time for their families than for the organization they work with and apart they have to abide by the head of family rules and regulations. But for the male workers, they are only subjected to organizational authority constraint. Also that the male workers are the bread winner of the family and there are some responsibilities they have to meet. To achieve these, they must be committed to the organization otherwise, they will lose their job and their responsibilities on their families will not be met. Based on this fact, male workers commitment is totally different from female workers commitment.

In testing the third hypothesis that married and single company's employees will not exhibit significant difference in their commitment to work, the result showed a significant difference $\left(\mathrm{X}_{\mathrm{c}}^{2}=77.045, \mathrm{X}_{\alpha}^{2}=41.337\right)$, rejecting the null hypothesis. The reason for the significant difference might be due to the fact that there were more married employees in the study than single employees. One of the reasons that may be given for the significant difference in the commitment to work of married and single employees is that effective job performance of married employees may be hindered by family commitments. But generally, married workers tend to show maturity and faithfulness to their job due to the fact that they are always concerned about their family responsibilities and other obligations, which they have to meet. Besides, they also aware of unemployment problem and if they should lose their jobs because of lack of commitment, it will be difficult for them to secure another one and their responsibilities will be affected adversely.

The fourth hypothesis was rejected. The finding tends to show the fact that there is a statistically significant difference $\left(\mathrm{X}^{2}=42.612, \mathrm{X}^{2} \mathrm{X}_{\alpha}{ }_{\alpha}=23.685\right)$ in the commitment to work of senior operative and junior operative workers. Truly, it is agreed that there is greater job satisfaction as people move up the hierarchy as said by Dalton et al (1980:49) cited in Ajila (2000). But this finding showed that junior operative workers are more committed to work than senior operative workers being that with their lower level of job satisfaction, they will be aspiring for high level and the only means to achieve this is through high commitment to work. Also that the difference in the commitment to work between senior and junior operative workers was due to differences between the two groups in terms of their educational attainment, as adapted from Ajila (2000), mighty not be true. The reason for this is that securing or holding a higher position in an organization may be by chance and apart, some junior operative workers might possess more educational qualifications than their respective bosses, but were not opportune to secure a better offer because of unemployment problem rising in the country. Finally, senior operative workers always feel relaxed and satisfied with their positions in the organization, but junior operative workers are always struggle to get them promoted to a higher level through their efforts and commitment to the organization.

\section{Policy Recommendations and Conclusion}

Following the results of the analysis above, it is clearly shown that labour commitment has significant impact on firm's productivity. Motivational factors, management styles have many effects on labour commitment. Good management involves workers to continue band exert high level of effort and readiness to work on behalf of the organization. However, from the result of data collected and interviewed given to the respondents, workers will not be committed to the organization if pay is not good. The commitment rate will be very low if the workers are not satisfied with the promotion system in the company and also the persistent delay in salary of the workers may lead to high rate of labour absenteeism, which will generate negative impact on the level of productivity.

Based on the above findings and observations, the researcher would like to make some recommendations, which will be very useful to the management of the Global Soap and Detergent Industries Limited, Ilorin and to other similar industries and these include:

An organization can be viewed as a system made up of independent parts. It is the functions and maintenance and well-being of the organization as a whole which will invariable increase workers commitment to work. In essence, it is very pertinent that management must provide necessary incentives in the manner that will boost workers' morale to work harder and be more committed to their work.

Management should shelve away the idea of leadership styles who believes that productivity and profit are the goals of an enterprise without considering the plight of the workers rather they should try as much as possible to make sure that workers are credited for a job well done. And apart from giving workers more pay, their promotion must also be regular.

Also, management should try as much as possible to adopt a system of inter-personal relationship in their corporation. This is because it is only through this that workers can be committed, even more committed to work. On the contrary, if workers are not given the free hand to relate with one another, participate in decision 
making process, the work will be frustrating, boring and may eventually lead or result to low level of commitment to the organization.

The management of the company should therefore look into the area of salary and promotion of staff towards increased productivity in the organization. Not only this, but also that the management should intensify and further encourage training and re-training of their staff at all levels.

The management should always ensure that whatever agreement reached with the union is met so that the cases of incessant strike will not always arise.

To conclude this proffered solution, the words of Ouchi (1981) that "the working organization is the family and every worker should be treated as member genuinely accepted by the management as key factor in the organization". There should therefore be harmony between the goals of organization with the goals of employees through making sure that immediate needs are recognized, appreciated and identified. With this, job satisfaction, commitment to work and higher productivity will be achieved.

\section{References}

[1]. Adetayo, J.O. and Salawu, R.O. (2000): "The Role of Motivation in Enhancing Productivity in the Banking Industry in Nigeria". A Case Study of First Bank of Nigeria Plc. IJBSS Vol. 6 No. 2, July 2000. Pp 88-100

[2]. Ajila, C.O. 1997. Job Motivation and Attitude to Work as Correlates of Productivity among Workers in Manufacturing Companies in Lagos State. Nigeria. Unpublished Ph.D Thesis submitted to the Department of Psychology O.A.U Ile-Ife Osun State, Nigeria.

[3]. Ajila, C.O. (2000): "Demographic Factors, Attitude to Work and productivity": A case study of some selected manufacturing Companies in Lagos state, Nigeria. IJBSS Vol. 2, July 2000. Pp 14-26.

[4]. Akindele, R.I. (1994): "How to Motivate Nigerian Workers". Quarterly Journal of Administration Pp. 337-349.

[5]. Anthony, E.A. (1996): The Impact of Adjustment Programme on Manufacturing Industries in Nigeria, 1986-1991; A Sample Study, African Development Review, African Development Bank, Vol. 8(1), page 61-96.

[6]. Anyanwu C.M (2000). Productivity in The Nigerian Manufacturing Industry, Paper Presented at the 9th Annual Conference of Zonal Research Units, held at Abeokuta, June 12-16th.

[7]. Aries, S. and Rizqi, M. (2013): "Analysis of the Effect of Attitude towards Works, Organizational Commitment, and Job Satisfaction, on Employee's Job Performance”. European Journal of Business and Social Sciences, Vol.1, No.10, pp 15-24.

[8]. Bassey, N. (1995): "The management of Corporate Survival in Nigeria." The Human Resource View. Paper Delivered at IPM Conference at Ibadan p.9.

[9]. Buchanan, B. (1974) Building organizational commitment: The socialization of managers in the organization.

[10]. Denison, E. F. (1962): "The Sources of Economic Growth in the United States and the Alternatives before Us." Supplementary Paper No. 13, New York, Committee for Economic Development.

[11]. Francois, P. and Roberts, J. (2002): "Relationships. Commitment and Labour Productivity Growth". Review of Economic Studies, Forthcoming. From http://www.google.com/search

[12]. Ghosal, A and Ghosh, SN (1964). "A Study of Productivity in Important Industries in India," Productivity Measurement

[13]. Review, Vol. 38

[14]. Hall, D.T., Schneider, B.,\& Nygren, H.T.(1970) Personal factors in organizational identification, Administrative Science Quarterly, 15, 176189.

[15]. Lowery, C., Beadles, N. \& Krilowicz, T. J. (2002). Note on the relationship among job satisfaction, organizational commitment, and organizational citizenship behavior. Psychological Reports, 91, 607-617. 1,No.6,pp34-51.

[16]. Meyer, J. P. and Allen, N. J. (1991) 'A Three-Component Conceptualization of Organizational Commitment', HumanResource Management Review, 1, 61-89.

[17]. Meyer, J.P. \& Allen, N.J. (1997) Commitment in the workplace, Thousand Oaks, CA: Sage Publications.

[18]. Miner, J.B. (1985a): "Executive Profiles. In the Practice of Management. "Columbus, OH: Merrill.

[19]. Miner, J.B. (1988): "Industrial-Organizational Psychology. Work Attitudes and Job Satisfaction”. New York: Random House. Pp. 115-139.

[20]. Mishra, J. and Morrissey, M.A. (1990) 'Trust in employee/employer relationships: A survey of West Michigan managers', Public Personnel Management, 19(4), 443-463.

[21]. Mitchell, T.R (1982): Motivation: New Directions for Theory, Research, and Practice. The Academy of Management Review, Vol. 7, No. 1, pp.80-88.

[22]. Mowday, R., Porter, L., and Steers, R. (1979) The Measurement of organizational commitment, Journal of Vocational Behavior, 14, 2, 224-247.

[23]. Ouchi, W.G. (1981): Theory Z. New York: Avon Books.

[24]. Pritchard RD, Paquin AR, DeCuir AD, Mc-Cormick MJ, Bly PR. 2002. Measuring and improving organizational productivity: an overview of ProMes, the productivity measure and enhancement system. In Improving Organizational Performance with the Productivity Measurement and Enhancement System: An International Collaboration, ed. RD Pritchard, H Holling, F Lammers, BD Clark, NY: Nova.

[25]. Salancik, G.R. (1977), Commitment and the control of organisational behaviour and belief, New direction for organisational behaviour, 154, Chicogo:St.Clair

[26]. Sarah, B., Jolian, M., Robert, M., and Karl, T. (2011): Workplace Performance, Worker Commitment and Loyalty. IZA Discussion Paper No. 5447.

[27]. Schermerhorn, J. R., Hunt, J. G., \& Osborn, R. N. (1985). Managing organizational behavior,(2ndEd.), New York

[28]. Scholl, R.W., (1981),Differentiating commitment from expectancy as a motivating force, Academy of management Review,6, 589-599.

[29]. Solow, Robert (1957). "Technical change and the aggregate production function". Review of Economics and Statistics 39 (3): $312-320$. JSTOR 1926047

[30]. Udabah S.I (2000). Productivity and Economic Growth, Paper Presented at the 9th Annual Conference of Zonal Research Units, held at Abeokuta, June 12-16th

[31]. Varsha, D. and Monika, B.Ms (2012): A Study about Employee Commitment and its Impact on Sustained Productivity in Indian AutoComponent Industry. European Journal of Business and Social Sciences, Vol. 